\title{
Making Sense of Converging Media
}

\author{
Kim Holmberg \\ Åbo Akademi University \\ Fänriksgatan 3 \\ 20500 Åbo, Finland \\ kim.holmberg@abo.fi
}

\author{
Timo Ketonen \\ Åbo Akademi University \\ Henriksgatan 7 \\ 20500 Åbo, Finland \\ timo.ketonen@abo.fi
}

\author{
Malin Brännback \\ Åbo Akademi University \\ Henriksgatan 7 \\ 20500 Åbo, Finland \\ malin.brannback@abo.fi
}

\begin{abstract}
This paper looks at Newspaper Publishers' approach to find new sources of revenue in the rapidly changing digital ecosystem. The design of new and viable business models is a real challenge in the changed media landscape, where consumers are increasingly online and obtain and share their news on multiple platforms including blogs and social media. Mobile media consumption is clearly a trend, which in turn requires new business models and new ways of engaging consumers in media content.
\end{abstract}

\section{Keywords}

E-newspapers, newspapers, publishing, media, disruption, business models, Delphoi, interviews.

\section{INTRODUCTION}

For a very long time printed newspapers have been a source of news and information, but this is now changing. Newspapers are changing rapidly as newspaper companies are trying to find new ways to reach their audiences and create new business models for the highly connected and online world.

The business model for printed newspapers is nearly 180 years of age: On the morning of September 3rd 1833 a new kind of newspaper "the Sun" went on sale on the streets of New York. It was made cheap: at one penny, it was one-sixth of the price of most other papers and it appealed to people who had not bought newspapers before. In hindsight it was a turning point because it introduced a new business model to the industry. The Sun's large circulation attracted advertisers, and the resulting revenue enabled the publisher to keep the price of the newspaper down and its circulation up. This model worked well for a long time. Today newspapers are in trouble.

The seeds for the downturn were sown in the mid 1990's with the introduction of the Internet. Nearly all the newspapers opted to offer their content, or at least part of their content for free on the Internet, in the hope of stacking up revenue from online advertising. Traditionally, advertising was the engine of newspaper profitability, the largest source of newspaper revenue and the key determinant of whether years were good or less good. Advertising sales is heavily dependent on a large readership, still the fundamental business model in the newspaper industry. Now advertising revenue is falling owing to the change in consumer behavior and the way advertisers are trying to engage consumers

Permission to make digital or hard copies of all or part of this work for personal or classroom use is granted without fee provided that copies are not made or distributed for profit or commercial advantage and that copies bear this notice and the full citation on the first page. To copy otherwise, or republish, to post on servers or to redistribute to lists, requires prior specific permission and/or a fee.

Academic MindTrek 2013, October 1-4, 2013, Tampere, FINLAND

Copyright 2013 ACM 978-1-4503-1992-8/13/10...\$10.00. on a multitude of new platforms including websites, online shops and social media. In the U.S. newspaper advertising is down to the level of 1950's, including online advertising. Hence the focus is now on bringing digital subscribership up in order to stay in the business.

In Finland the print editions of newspapers still have a large readership, but the question is for how long. In the last few years the print circulation has come down by some $4-5$ per cent per annum. Will the change in consumer behavior take one generation (20 years) or will there be a faster transition towards an all-digital publishing model? The majority of print subscribers represent older generations $(50+)$. How will the revenue stream change over time? Today approx. $49 \%$ of newspaper income in Finland is derived from subscriptions and $51 \%$ from advertising revenue [1].

The newspaper industry is struggling to find viable new business models in online newspapers, which is demonstrated by the many different forms of e-newspapers that we have today. Currently enewspapers come basically in three forms: 1 ) a web browser based version of the newspaper, 2) a digital copy of the printed newspaper, usually a 1to1-replica of the printed newspaper (ePaper), or 3) a newspaper application especially designed for tablet computers and other handheld devices such as smartphones. The multitude of different formats is also present in the somewhat confusing terminology that is used about electronic newspapers and the same term, e-newspapers, have been used for both online newspapers [2] and for newspapers published on e-paper technology $[3 ; 4]$.

The way news is reported is also changing. Social media is allowing anyone to become a reporter and publisher of news. Anyone can publish photos, stream real-time video or report in their blogs about events they have witnessed. News companies are encouraging people to share their photos from and experiences about newsworthy events all around the world. We have shifted from being users and consumers of news to also be producers and reporters. News have become more interactive as we participate in online discussions about them, and news have become more mobile as we read and share them from our mobile devices where ever we are, but how are the traditional newspaper publishers keeping up with these changes in consumer behavior and how are they preparing for changes in the future?

Also the way we measure the engagement of media audiences is shifting. The transition to a more interactive media environment, like the transition to an increasingly fragmented media environment, has undermined traditional analytical approaches to media audiences [5]. The focus for publishers has reoriented around attracting the most desirable 'eyeballs' that are highly valued by advertisers, instead of trying to appeal to the mass audiences traditionally targeted by newspapers, magazines and TV. A challenge to researchers in media behavior is to develop a 
thorough understanding of the growing array of ways in which audiences learn about and locate relevant content, as well as how they interact with media and each other. It is relevant to understand how people engage in media and to measure the impact of sharing and recommending news and items for purchase.

Meyer [6] wrote that "somewhere inside the traditional newspaper organization, there still exists the capacity to salvage a transformed, sustainable, socially useful news business", but how companies are preparing for this change is unclear. The goal of this research is to seek answers to how newspaper publishers in Finland are preparing for this shift, and to investigate the present and the future of e-newspapers in Finland and the business models connected to them.

\section{LITERATURE REVIEW}

The way we discover, consume and share news is changing. In December 2008 according to a survey by the Pew Research Center [7], $40 \%$ of the respondents received their news online, while $38 \%$ got their news from newspapers, and nearly $60 \%$ of those under 30 years of age got their news from online sources. In a later study by Pew Project for Excellence in Journalism [8] 41\% of Americans said they get most of their news online while only $31 \%$ get their news from newspapers. In the age group of $18-29$ years $65 \%$ get their news online. The results show that online news consumption is increasing at the expense of the printed newspapers. The Pew Internet and American Life Projects Project for Excellence in Journalism $[9 ; 10 ; 11]$ have shown that one third of mobile phone owners access news from their cell phones and that only slightly fewer people have personalized their news. The study also showed that $37 \%$ of Internet users have contributed to online news by commenting or sharing them forward to their online social networks. Social media has changed the way we receive our news. Instead of going to newspapers' websites or searching for news with online search engines, we receive news and content from our social networks on Facebook, Twitter, and other social media sites. We do not have to go to the news anymore, the news are coming to us in form of recommendations and links from our online friends and acquaintances. We are even relying on our social networks to provide us with news [9].

Newspapers are at the brink of a major change. Initially newspapers focused more on protecting their print business rather than prioritizing new electronic forms of publishing [12], however, things are changing. The advertisers have been reluctant to invest in online ads, although this may be changing as more and more money is spent in online advertising [13]. Circulation of newspapers is declining [6] and the revenues are decreasing. While online advertising revenues are increasing (14\% in 2010 to 25.8 billion USD in total) [13], newspapers saw a fall of $6.4 \%$ in their revenues [14]. There is a great need for new business models when the traditional models have not been successfully transferred to the new media [15].

Many actors are dependent on each other when it comes to enewspapers. Publishers are dependent on device producers and advertisers, advertisers are dependent on readers, device producers are dependent on publishers [16]. Earlier research has suggested that there may be various advantages for the different actors. The benefits of e-newspapers for publishers include decreased publication and distribution costs and an increase in the amount and type of information they can offer. The news can be updated anytime, they can be interactive and include some added services, and new subscription packages may attract new audiences [17] increasing the overall reachability that does not have to be limited by geography [2]. There may also be environmental advantages in e-newspapers [17]. Advantages for the readers include the possibility to comment on the articles, better availability anytime and anywhere, enhanced experience through multimedia, better relevance through personalized content, and increased sociability through community building and sharing of news [18]. For the advertisers the main advantages come from mass coverage and improved reachability, and possibilities for profiling users and showing them targeted advertisements [18].

\section{METHODS}

Predicting the future is never an exact science, however, there are methods that can minimize uncertainties and increase the accuracy of predictions of the future. One such method is the Delphoi method [19], named after the Oracles of Delphoi in the ancient Greece. The Delphoi method collects anonymous answers in several iterations of a set of questions from a panel of experts. After each round of questions the answers are summarized and the respondents are given the possibility to comment or revise their answers. Originally the goal of the method was that after a number of iterations consensus among the experts would be reached, however, the method has evolved and depending on the research goals reaching consensus is no longer considered to be a requirement [20]. In the Delphoi method a group of experts from the area of research are chosen to be the oracles $[20 ; 21 ; 22]$. The size of the group and also the number of iterations may vary and depend on the number of available experts. The oracles of this research included 9 experts that worked as chief editors, directors of research, or in related positions in Finnish media companies that publish newspapers. The members of the expert panel answered or commented on 9 open ended questions or statements. The first round was conducted in July 2011 and the second and final round was done in August 2011.

The results gained with the Delphoi method were complemented by a qualitative analysis of interviews conducted in 2012-2013. The interviews were conducted in order to prepare for case studies of the strategic choices of publishing firms. Within this framework the theory draws upon research conducted by Zott and Amit [23; 24]: "We hypothesize that the design of an entrepreneurial firm's business model, which is centered specifically on the themes of novelty and/or efficiency, is associated with the firms' performance."

\section{RESULTS}

\subsection{Delphoi expert panel}

According to the nine respondents in the Delphoi expert panel in the current situation in Finland printed newspapers are still important and the e-newspapers are in a way a supplement or an additional service to them, but e-newspapers are evolving. In 2011 e-newspapers are mostly pdf versions of the printed newspapers (although some newspapers have already launched their versions that differ from the printed newspaper) and the importance of e-newspapers was seen as marginal. However, the online e-newspapers have managed to reach a strong position measured by number of users, as more and more readers seem to be satisfied with the news they get for free from newspapers' websites. Online newspapers have not yet been able to breakthrough neither as a new way to subscribe a newspaper nor 
as a new way to make money. One of the respondents stated that perhaps newspapers went too far with distributing online news for free and now newspapers want the consumers to start paying for electronic news. To get a user that is used to free content to pay for the same thing newspapers need to bundle up a very attractive alternative so that the consumers will be prepared to pay for it.Enewspapers were seen by the expert panel as a way for newspapers to gain new readers, and especially as a way to get young people to read newspapers. In a situation where publishing of printed newspapers is declining, the overall number of readers is increasing through various electronic newspapers. At the same time newspapers are protecting the printed newspapers by keeping the price of e-newspapers so high that buying only the e-version is not beneficial.

The respondents of the expert panel had some divided opinions about how the e-newspapers will develop in the future. Some predicted that e-newspapers will have many different forms and variations, designed for specific reading situations and for certain reader groups. Some respondents argued that in the future newspapers will be read from a web browser, while others predicted that an increasing number of newspapers will have their versions adapted for different reading devices (such as tablet computers). Most of the respondents agreed that in ten years' time e-newspapers will occupy a great portion of the room that printed newspapers currently have, measured in both the amount of time and money that users (and advertisers) are spending.

The respondents agreed that the pressure for paid content will most likely increase, but that the crucial question is whether readers will want to have a whole e-newspaper instead of the printed newspapers or do they want selected news stories like in online news. Only for the first alternative it is possible to put a sufficient price in order to maintain the current size of newsrooms. If newsrooms are forced to become smaller, the amount of online content will also reduce. According to the expert panel this situation will probably demand either differentiated content production or strong localization. The respondents see that newspapers will increasingly invest in developing electronic content and mobility will break through during the next couple of years. The content of newspapers may be bundle according to user groups of which the consumers are willing to pay for.

Most of the respondents felt that the future is looking relatively good, although the distribution is slowly decreasing and young people switch to online and mobile services. The respondents in the expert panel stated that journalism is not very different no matter if it is done for printed or electronic paper. The respondents were confident that the printed newspapers will be around for years to come, for decades even according to a couple of respondents, but as a commercial place for adds and at the same time as an source of income for publishers their meaning will decrease.

According to the respondents cost efficiency of distribution and getting the printed newspapers delivered to peoples' homes are crucial for the survival of the printed newspapers. The experts believe that people want a printed newspaper, as long as it is possible to deliver it to their homes.

In electronic distribution many costs are reduced or they disappear altogether (e.g. paper, press, distribution). In theory newspapers could be sold to the consumers a lot cheaper, especially if advertisers still can reach every reader no matter the distribution channel. At the same time the pressure to increase the price of the printed newspaper may increase, if it is delivered to fewer readers than today. It may become a luxury product that costs significantly more than today.

The respondents believed that an increasing amount of the income will come from electronic content. Newspapers' websites have a lot of traffic and the growth in online advertising will continue for several years. In e-newspapers there are better possibilities to target content and advertisements so that the customer can choose and pay only for content that they are interested in. The respondents argued that the pressure to invest in e-newspapers comes from two directions; partly from increased expenses in producing and delivering printed newspapers while the volumes go down, and partly from changing consumer behavior and the advertisers desire to follow this. The panel believed that newspapers that invest only in printed newspapers will not be successful, because all the time an increasing part of the readers will find the news and information they want from electronic newspapers. At the same time it is important to remember that content is still most important, not the distribution channel. A newspaper is not tied to paper, but a newspaper should produce interesting, reliable, and desired local content, no matter the format.

According to the respondents there are plenty of benefits in enewspapers. The benefits come mainly from cost savings in production and distribution, and increased profits due to increased reachability and possibility to reach new audiences. Different distribution channels guarantee a complete service to the customers and give the advertisers the possibility for increased reachability. If there are plenty of readers then advertising space becomes attractive, but competition between different advertising media may press the price down.

One of the disadvantages seen by the expert panel was that it will require some more development work before functioning business models are discovered and operational. Before that happens newspapers are forced to invest in many different online activities that will not give immediate return in form of profits. Some of the respondents felt that the e-newspapers may decrease the distribution of printed newspapers and if it is too cheap it will undermine profits. If it is priced right it should not be a problem that same content is shared in different formats. One concern was how the advertisements can be displayed in e-newspapers and whether the consumers would want to see advertisements in enewspapers.

The panel of experts stated that in the near future consumers are facing a multitude of choice in devices and there will be many different versions of e-newspapers for different specific reading situations. News can be read from many other devices at home, not just on the computer, tablet or smartphone. It was believed by some respondents that laptops will stand their positions and that a normal desktop computer that is used at work will remain to be a popular user interface. In the future mobile devices will be lighter than now, like printed paper when it comes to the reading experience. It is possible and likely even that we will have the first versions of smart papers that can be bent and folded. Enewspapers will transform to a service package where news are just part of the whole package. It is possible that the newspapers will include elements of multimedia or that it is possible to link to additional information or earlier published material of the topic which brings added value to the news. Movie clips will probably become part of newspapers and interactivity may increase.

The respondents advised that in short term newspapers should understand that e-newspapers are here to stay and they should be 
developed further, perhaps by the terms of online environment and mobile devices rather than the traditional newspaper and content. More resources should be allocated to investigate the change in media consumption and the development of content creation based on target group thinking. The panel agreed that coproduction and cooperation between newspapers should also be developed, so that everybody do not have to reinvent the wheel. Media companies should carefully analyze which success factors are still viable and how they could be strengthened and transferred to other distribution channels and platforms, but at the same time they should keep up with different formats and in development of them, so that they are ready when some channels start to pull. Although the respondents warned that newspapers should not rush into anything, the respondents also predicted that the breakthrough in electronic services may be surprisingly quick in a couple of years.

The panel agreed that long term plans depend on both device manufacturers and also changes in consumer behavior, and that newspapers and advertisers go where consumers want to receive their content. Hence, it is important to continue to research consumer behavior and to react systematically on changes and new developments. It is also important to increase cooperation and create networks to divide costs and to share experiences.

The panel felt that it is possible and likely even that e-newspapers may get clearly more users than traditional newspapers and hence companies have to invest in the development of different channels for profits, even though they will for a long time be small and insignificant as profit channels. But as the use of e-newspapers increases, so does the demand to place advertisements in them. Companies should learn to use e-newspapers in a efficient way and avoid drowning them in advertising. One of the respondents stated that over flooding the e-newspapers with advertisements is the biggest risk for e-newspapers to fail. Content has to be kept unique and interesting enough so that it has real market value to the readers even in the future among all the content that is free.

\subsection{Interviews}

In addition to the Delphoi method we have carried out a qualitative study based on in-depth interviews with media experts in four countries. 75 interviews were carried out in Finland, Sweden, the U.K. and USA. The interviews have involved media executives, commercial directors and editors-in-chief, as well as business managers with an $R \& D$ focus. A majority of the interviews (55) were conducted with Finnish publishers and representatives of related industry associations.

The results from the interviews indicate that a major business paradigm shift is underway. We have identified four key drivers of change as a pattern discussed in the course of the interviews:

- Consumer Behavior (time spent on media and how media is consumed)

- Cost of Print \& Distribution (particularly the cost of physical distribution)

- Disruptive Technology (the new 'ecosystem' with tablets and smartphones)

- $\quad$ The Change in Advertising (mass marketing vs. targeted content marketing)

There is an increased "sense of urgency" among the publishing firms and the attitude of industry leaders has changed in the past two years, which is clear when comparing the results from the
Delphoi expert panel and those of the interviews conducted later. The research work was started in 2011 and at that time the change in consumer behavior and advertising was not as strongly felt by Nordic newspaper publishers as it is today. Now the general sentiment is that the business models need to be reviewed and investments into digital transformation are a necessity. Based on the interviews, the year 2013 seems to be the year of 'paywalls', which means that digital content is no longer free online and several models for offering digital content on mobile platforms have been launched. Some Finnish newspapers have already followed the example set by The New York Times (NYT) in March, 2011. The so called 'metered paywall' only allows media audiences to read a limited number of articles for free in order to build a digital subscription base. For The New York Times this seems to be a successful measure, with already 700,000 paid digital subscribers and 1.13 million who pay for digital content of The Times (some subscribe to a combination of digital content and print). Total subscriptions for NYT are thus up by $18 \%$ in the first quarter of 2013, and digital subscriptions are up by $32 \%$.

The interviews reveal that some firms have chosen to stick to the old business model with a technological focus on the print based business model for as long as possible. These companies are efficiency centered and the main part of revenue is derived from the old print based business model (bottom left in figure 1). Some publishers look at even a greater degree of efficiency through industry consolidation (top left in figure 1), which required investments into corporate acquisition and competencies in finding synergies within the acquired framework of newspapers. Several publishers (to the right in the figure 1 below) have invested into a digital transformation with a certain degree of incremental improvement of the printed products. Digital transformation means investment into new products and services in the digital ecosystem, including mobile applications. The last category of publishers in the top right corner of figure 1 clearly have a novelty centered business model and a more aggressive "Digital First" approach to creating the future. These firms have invested both in the creation of digital publishing platforms and the analysis of reader engagement based on collection of data related to the behavior of the subscriber base. These companies are most often "global brands", with an audience across the world.

The aim of the interviews was to prepare case studies of publishing firms in order to analyze the strategic choices of newspaper publishers with regard to the performance of these firms in both economic terms (measured in terms of revenue from digital services) and in terms of the engagement of readers (measured in terms of digital subscriber base). The different strategic choices are illustrated in figure 1 below. 


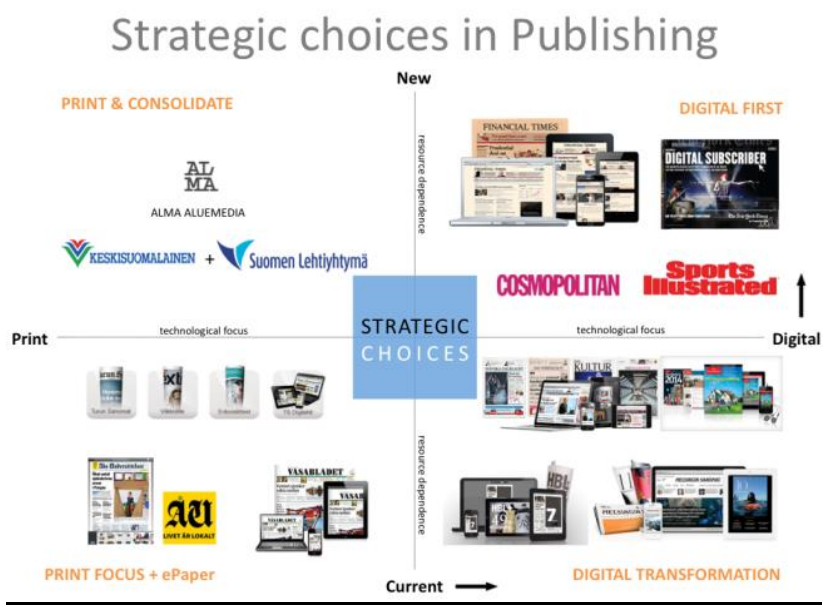

Figure 1. Strategic choices in publishing

\section{CONCLUSIONS}

The results from the Delphoi expert panel indicate that a change is expected as user behavior is changing and new platforms to read newspapers on are being introduced. The later interviews reveal that that change has already started and that the publishers feel an urgency in deciding which path to choose and where to invest. The results show how different companies have chosen different approaches to meet the digital demand that a changing consumer behavior is bringing. A possible future research direction would be to investigate which approach has proven to be most successful.

\section{ACKNOWLEDGMENTS}

This project was funded by the Research Foundation for the Media Industry in Finland and a number of corporate partners.

\section{REFERENCES}

[1] Finnmedia - The Federation for the Finnish Media Industry

[2] Bokesoy, D. (2008). E-newspapers: Revolution or evolution? Scroll. Essays on the Design of Electronic Text, vol. 1, no. 1. Retrieved from http://fdt.library.utoronto.ca/index.php/fdt/article/viewArticle /4902/1758 on June 10, 2011.

[3] Eriksson, C.I., Åkersson, M., Svensson, J. \& Fredberg, T. (2007). Introducing the e-newspaper: Identifying initial target groups. Journal of Media Business Studies, vol. 4, no. 3, pp. 41-62.

[4] Åkersson, M., Ihlström, C. \& Svensson, J. (2005). How would you like your e-newspaper?: converging the best of two worlds. In the Proceedings of the HCI international 2005: 11th international conference on human-computer interaction, July 22-27, 2005, Caesars Palace, Las Vegas, Nevada, USA. Retrieved from http://urn.kb.se/resolve?urn=urn:nbn:se:hh:diva-424 on June 9, 2011

[5] Napoli, P. Audience Evolution: New Technologies and the Transformation of Media Audiences. Columbia University Press, New York, 2011.
[6] Meyer, P. (2008). Vanishing newspaper: Saving journalism in the information age (2nd edition). Columbia, MO, USA: University of Missouri Press, 2009.

[7] Pew Research Center (2008). Internet Overtakes Newspapers as News Outlet. PEW RESEARCH CENTER FOR THE PEOPLE \& THE PRESS. Retrieved from http://pewresearch.org/pubs/1066/internet-overtakesnewspapers-as-news-source on June 4, 2011.

[8] O'Dell, J. (2011). For the First Time, More People Get News Online Than From Newspapers. Mashable, March 15, 2011. Retrieved from http://mashable.com/2011/03/15/onlineversus-newspaper-news/ on March 15, 2011.

[9] Project for Excellence in Journalism (2010a). New mdia, old media. HOW BLOGS AND SOCIAL MEDIA AGENDAS RELATE AND DIFFER FROM THE TRADITIONAL PRESS. The Pew Internet and American Life Projects Project for Excellence in Journalism, May 23, 2010. Retrieved from http://www.journalism.org/node/20621 on June 2, 2011.

[10] Project for Excellence in Journalism (2010b). The new news landscape: Rise of the Internet. Understanding the participatory news consumer. The Pew Internet and American Life Projects Project for Excellence in Journalism, March 1, 2010. Retrieved from http://pewresearch.org/pubs/1508/internet-cell-phone-usersnews-social-experience on May 20, 2011.

[11] Project for Excellence in Journalism (2011). Navigating news online. WHERE PEOPLE GO, HOW THEY GET THERE AND WHAT LURES THEM AWAY. The Pew Internet and American Life Projects Project for Excellence in Journalism, May 9, 2011. Retrieved from http://www.journalism.org/analysis_report/navigating_news_ online on June 2, 2011.

[12] Boczkowski, P.J. (2004). Digitizing the news: Innovation in online newspapers. Cambridge, MA, USA: MIT Press, 2004.

[13] Olmstead, K., Mitchell, A. \& Rosenstiel, T. (2011a). Online: Key questions facing digital news. Pew Research Center's Project for Excellence in Journalism. The State of the News Media - An Annual Report on American Journalism 2011. Retrieved from http://stateofthemedia.org/2011/online-essay/ on June 3, 2011.

[14] Olmstead, K., Mitchell, A. \& Rosenstiel, T. (2011b). Key findings. Research Center's Project for Excellence in Journalism. The State of the News Media - An Annual Report on American Journalism 2011. Retrieved from http://stateofthemedia.org/2011/overview-2/key-findings/ on June 3, 2011.

[15] Ihlström, C. \& Kalling, T. (2007). Proposing a business model framework for the e-newspaper introduction. In Proceedings of ECIS 2007, the 15th European Conference on Information Systems, St. Gallen. June 7-9., paper 58. Retrieved from http://aisel.aisnet.org/ecis2007/58/ on May $25,2011$.

[16] Ihlström, C., Åkesson, M., Bergqvist, M., \& Ljungberg, J. (2009). Forming a value network - analyzing the negotiations between actors in the e-newspaper case. In Proceedings of HICSS'42, Big Island, Hawaii, January 5-8, 2009. Retrieved from 
http://www.computer.org/portal/web/csdl/doi/10.1109/HICS S.2009.735 on June 2, 2011.

[17] Ihlström, C. Åkersson, M. \& Nordqvist, S. (2004). From print to web to e-paper - the challenge of designing the enewspaper. In Proceedings of the Eight ICCC International Conference on Electronic Publishing, Brasilia, Brazil, June 2004. Retrieved from

http://www.diginews.se/files/040627_elpub_carina_maria_sti g.pdf on June 9, 2011.

[18] Åkersson, M. (2006). Mobile service value - presenting the newspaper publisher view on how to attract users and advertisers. In Proceedings of IRIS'29 in Denmark. Retrieved from

http://www.diginews.se/files/IRIS_29_final_submission.pdf on May 12, 2011.

[19] Dalkey, N. \& Helmer, O. (1963). An experimental application of the Delphi method to the use of experts. "Management Science", 9 (1963): 458-467.
[20] Landeta, J. (2006). Current validity of the Delphi method in social sciences. "Technological Forecasting \& Social Change”, 73 (2006): 467-482.

[21] Loo, R. (2002). The Delphi method: a powerful tool for strategic management. "Policing: An International Journal of Police Strategies \& Management", 25 (2002): 762-769.

[22] Grisham, T. (2009). The Delphi technique: a method for testing complex and multifaceted topics. International "Journal of Managing Projects in Business", 2 (2009): 112130.

[23] Zott, C., Amit, R. Business Model Design and the Performance of Entrepreneurial Firms. Organization Science Vol. 18 No.2, March-April 2007, pp.181-199.

[24] Zott, C., Amit, R. and Massa, L. The Business Model: Recent Developments and Future Research. Journal of Management Vol. 37 No.4, July 2011. 